\section{Evaluation of Pumpkin Cultivars for Powdery and Downy Mildew Resistance, Virus Tolerance, and Yield}

\author{
Anthony P. Keinath ${ }^{1}$ and Virginia B. DuBose ${ }^{2}$ \\ Department of Plant Pathology and Physiology, Clemson University, Coastal \\ Research and Education Center, Charleston, SC 29414-5332
}

Additional index words. Cucurbita pepo, Cucurbita maxima, papaya ringspot virus, Pseudoperonospora cubensis, Sphaerotheca fuliginea, watermelon mosaic virus, zucchini yellow mosaic virus

\begin{abstract}
Twenty-six cultivars and two numbered selections of Cucurbita pepo L. pumpkin and four cultivars of $C$. maxima Duchesne pumpkin were evaluated in field experiments in 1996 and 1997 in Charleston, S.C. The four C. maxima cultivars ('Mammoth Gold', 'Big Max', 'Rouge Vif d'Etamps', and 'Lumina') and three C. pepo cultigens (HMX 6686, HMX 6688, and Magic Lantern) had lower powdery mildew [Sphaerotheca fuliginea (Schlechtend.:Fr.) Pollacci] severities than did the other $C$. pepo cultivars. Overall, $C$. maxima cultivars also had less foliage showing virus symptoms and less downy mildew [Pseudoperonospora cubensis (Berk.\& M.A. Curtis) Rostovzev] than did C. pepo cultigens. Mid- and long-season cultigens of both species ( $\geq 100$ days to maturity) produced a greater number of marketable-quality fruit than did short-season cultigens. Cucurbita maxima and $C$. pepo produced similar numbers of marketable fruit; however, more potential marketable yield was possible in $C$. maxima since most fruit were affected by virus. The $C$. pepo cultigens Spookie, HMX 6686, and Spooktacular produced the greatest numbers of marketable fruit. In general, no cultigens were well-adapted to the growing conditions of the humid coastal plain of the southeastern United States.
\end{abstract}

Pumpkin can be a profitable crop when grown for the Halloween market. Because of the high potential return per hectare, pumpkin is particularly suited for growers with limited acreage or those located near urban areas. To yield well under current management practices, pumpkin requires expensive inputs, such as white or black polyethylene mulch and regular insecticide and fungicide applications (Kemble et al., 1997). Because pumpkin has a long growing season (90 to $120 \mathrm{~d}$ ) and is planted later than most warm-season vegetable crops, vines must be protected from several foliar pathogens. In the southeastern United States, both downy mildew and powdery mildew reduce yields (Bost et al., 1991; Shoemaker, 1994). In addition, viruses such as papaya ringspot virus (PRSV), watermelon mosaic virus (WMV), and zucchini yellow mosaic virus (ZYMV) infect $C$. pepo and reduce marketable yields in this region (Schultheis and Walters, 1998). Little infor-

Received for publication 26Feb. 1999. Accepted for
publication 25 Aug. 1999. Technical contribution
no. 4472 of the South Carolina Agriculture \& For-
estry Research System, Clemson. We gratefully
acknowledge Warren May III for technical assis-
tance and Ted Superak, Harris-Moran Seed Co., for
providing numbered, powdery mildew-resistant se-
lections. Salaries were supported in part by Hatch
Project SC01628. The cost of publishing this paper
was defrayed in part by the payment of page charges.
Under postal regulations, this paper therefore must
be hereby marked advertisement solely to indicate
this fact.
${ }^{1}$ Associate Professor. e-mail: tknth@ @lemson.edu ${ }^{1}$ Associate Professor. e-mail: tknth
${ }^{2}$ Agriculture/Animal Associate II.

HortScience, Vol. 35(2), April 2000
Pumpkin cultivar evaluations were conducted at the Coastal Research and Education Center, Charleston, S.C., on Yonges loamy fine sand (fine-loamy, mixed, thermic, Typic Albaquults). The experiments were randomized complete blocks with three replications in 1996 and four replications in 1997. Each plot was a single row of eight plants.

In previous cultivar evaluations, pumpkins with different maturity dates were all seeded or transplanted and harvested at the same time, which may not provide an equitable yield comparison among cultivars (Bost et al., 1991; Precheur et al., 1994, 1998). In our experiments, three seeding and transplanting dates were used so that all cultigens reached maturity at the same time, because harvest date is important for marketing pumpkins. Thirtytwo pumpkin cultigens were separated into three groups based upon days to maturity (DTM) as indicated by seed company descriptions. Long- (110-120 d), mid- (100-105 d), and short-season (85-95 d) pumpkins were seeded on 11 June, 21 June, and 1 July 1996 , respectively, and 27 June, 8 and 18 July 1997 , respectively. Seedlings within each maturity date were transplanted to the field 10 or $11 \mathrm{~d}$ after seeding, so that the harvest dates would coincide. Plants were spaced 0.9 m apart within rows in 1996 and $1.2 \mathrm{~m}$ apart in 1997. Plots were separated by $3.0 \mathrm{~m}$ of space within rows. Row spacing was $1.8 \mathrm{~m}$ on bed center and every other row was planted. Transplants that died within 1 week of transplanting were replaced so that all plots contained eight plants. In 1996, but not in 1997, vines were moved into the $1.8-\mathrm{m}$-wide area until late in the season because of sprayer limitations.

Before planting, $900 \mathrm{~kg} \cdot \mathrm{ha}^{-1}$ of $10 \mathrm{~N}-4.4 \mathrm{P}-$ $8.3 \mathrm{~K}(1996)$ or $670 \mathrm{~kg} \cdot \mathrm{ha}^{-1}$ of $15 \mathrm{~N}-0 \mathrm{P}-12.5 \mathrm{~K}$ fertilizer (1997) were broadcast before raised beds were shaped and covered with white-onblack polyethylene mulch. Plots were sidedressed in the alleys on 25 July in both years with $220 \mathrm{~kg} \cdot \mathrm{ha}^{-1} 10 \mathrm{~N}-4.4 \mathrm{P}-8.3 \mathrm{~K}$. For weed control, bensulide( $S$-2-benzenesulfonamidoethyl $O, O$-di-isopropyl phosphorodithioate ) (3.4 $\mathrm{kg} \cdot \mathrm{ha}^{-1}$ a.i.) was applied preplant to alleys in 1996 and clomazone \{2- [(2-chlorophenyl) methyl]-4,4 dimethyl-3-isoxazolidinone $\}$ (1.1 $\mathrm{kg} \cdot \mathrm{ha}^{-1}$ a.i.) was broadcast preplant in 1997. Sethoxydim \{2-[1-(ethoxyimino)butyl]-5-[2(ethylthio) propyl]-3-hydroxy-2-cyclohexene1-one $\}\left(0.31 \mathrm{~kg} \cdot \mathrm{ha}^{-1}\right.$ a.i.) also was applied to control grasses in 1997. To manage insects, maximum labeled rates of esfenvalerate $[(S)$ $\alpha$-cyano-3-phenoxybenzyl(S)-2-(4-chlorophenyl)3 -methylbutyrate] or endosulfan $(6,7,8,9,10,10$ hexachloro-1,5,5a,6,9,9a-hexahydro-6,9methano-2,4,3-benzodioxathiepin 3-oxide) were applied in alternate weeks from planting until harvest both years; in 1997, Bacillus thuringiensis and permethrin [3-phenoxybenzyl $(1 R S)$-cis,trans-3-(2,2-dichlorovinyl)-2,2dimethylcyclopropanecarboxylate] also were used. In 1996, the fungicides chlorothalonil (tetrachloroisophthalonitrile) - triadimefon [1(4-chlorophenoxy)-3,3-dimethyl-1-(1H$1,2,4$,-triazol-1-yl)-2-butanone] (1.7 or 2.5 
$\mathrm{kg} \cdot \mathrm{ha}^{-1}$ a.i. chlorothalonil plus 0.09 or 0.13 $\mathrm{kg} \cdot \mathrm{ha}^{-1}$ a.i. triadimefon) or maneb (manganese ethylenebisdithiocarbamate) (1.3 or $1.8 \mathrm{~kg} \cdot \mathrm{ha}^{-}$ ${ }^{1}$ a.i.) plus benomyl [methyl 1-(butylcarbamoyl) benzimidazol-2-ylcarbamate] $(0.14$ or 0.28 $\mathrm{kg} \cdot \mathrm{ha}^{-1}$ a.i.) were applied in alternate weeks to manage powdery mildew, and metalaxyl $[N$ (2,6-dimethylphenyl)- $N$-(methoxyacetyl)-DLalanine methyl ester] - chlorothalonil ( 0.20 or $0.30 \mathrm{~kg} \cdot \mathrm{ha}^{-1}$ a.i. metalaxyl plus 1.6 or 2.4 $\mathrm{kg} \cdot \mathrm{ha}^{-1}$ a.i. chlorothalonil) or fosetyl-aluminum [aluminum tris $(O$-ethyl phosphonate)] $\left(1.8\right.$ or $4.5 \mathrm{~kg} \cdot \mathrm{ha}^{-1}$ a.i. $)$ were applied in alternate weeks to manage downy mildew. All fungicides were used at lowest labeled rates (first rate given above) from 17 July until 3 weeks before harvest, when maximum labeled rates (second rate given above) were substituted. From 16 July to 8 Aug. 1997, $1.8 \mathrm{~kg} \cdot \mathrm{ha}^{-}$ ${ }^{1}$ a.i. maneb or $1.6 \mathrm{~kg} \cdot \mathrm{ha}^{-1}$ a.i. chlorothalonil was applied weekly to control foliar pathogens. From 13 Aug to 26 Sept., fungicides were applied as in 1996 but maximum rates were used the entire season.

Severity of powdery and downy mildew was rated in all plots with the Horsfall-Barratt scale (Horsfall and Barratt, 1945) $(1=0 \%$ leaf surface area diseased to $12=100 \%$ of leaf surface diseased) four times at 7- to 10-d intervals beginning 1 week after the first transplanting. Because identifying individual cucurbit viruses is difficult based on foliar symptoms (Zitter et al., 1996), an overall rating for percentage of leaf area affected with virus symptoms was made with the Horsfall- Barratt scale on 29 Aug. 1996 and 16 Sept. 1997. To identify which viruses were present in the fields, two and three composite foliage samples in 1996 and 1997, respectively, were assayed with enzyme-linked immunosorbent assay (ELISA) for cucumber mosaic virus, PRSV, squash mosaic virus, WMV, and ZYMV. All fruit with at least $50 \%$ of the surface deep orange were harvested from each plot on 13 Sept. 1996 and on 23 and 30 Sept. and 7 Oct. 1997. Fruit were weighed and separated into marketable and nonmarketable quality. Fruit considered marketable had firm flesh with no decay, intact, firm stems, and either no colorbreaking or surface disfiguration due to viruses (1996) or <20\% surface area with virus symptoms (1997).

Percentage of leaf surface area diseased was calculated from the midpoints of the ranges represented by Horsfall-Barratt ratings (Horsfall and Barratt, 1945). Percent disease severity and yield data were subjected to analysis of variance with PROC GLM of SAS version 6.12 (SAS Institute, Cary, N.C.). All data were checked for normality and equality of variance before analysis; data for percentage of disease severity and number of fruit were transformed to square-roots. The WallerDuncan $\mathrm{k}$ ratio $t$ test was used to separate cultigen means, except for number of marketable fruit in 1996, where Dunnett's $t$ test was used to determine which cultigens produced mean numbers of fruit significantly $>0$. In addition, preplanned, single-degree-of-freedom contrasts were calculated to compare yields for different groups of cultigens based on species, days to maturity, fruit size, growth habit, and commercial type.

\section{Results}

Powdery mildew. Powdery mildew was the most prevalent foliar disease in both years, was more severe in 1996 than in 1997, and, on susceptible cultivars, was not completely controlled by alternate-week fungicide applications (Table 1). In both years, C. maxima cultivars had less powdery mildew overall than did $C$. pepo cultigens $(P=0.0001)$.

When ratings for both years were combined and analyzed together, there was a significant genotype $\times$ year interaction $(P \leq$ $0.0001)$, probably because a few cultivars, such as 'Big Autumn', 'Oz', and 'Tom Fox', were severely diseased one year but had less mildew the other year (Table 1). However, despite this interaction, 'Wizard,' 'Happy Jack,' and 'Spookie' were ranked among the most susceptible cultivars in both years, and 'Magic Lantern' and 'Lumina' had low levels of mildew both years. Overall, the cultigens with the lowest ratings (most resistant) were HMX 6688, Magic Lantern, and HMX 6686, and the $C$. maxima cultivars Rouge Vif d'Etamps and Lumina.

Downymildew. Downy mildew was present both years and, similar to powdery mildew, progressed faster in 1996 than in 1997. However, downy mildew increased late in the season in 1997 and contributed to foliage senescence. The highest mean mildew rating on 19 Aug. 1996 was 54\% for 'Rocket,' but on 5 Sept. 1997, the highest rating was only 3.6\% for both 'Connecticut Field' and 'Howden' (Table 1). In both years, C. maxima was less susceptible to mildew than was $C$. pepo $(P \leq$ 0.001). 'Big Max' and 'Mammoth Gold', both $C$. maxima cultivars, were among the cultigens with the lowest ratings both years.

Virus symptoms. Leaves of all cultivars were distorted and mottled with virus symptoms by the end of August in both years. In 1996, ZYMV and PRSV were detected in all samples and WMV was detected in half of the samples. In 1997, samples of distorted leaves were positive for both ZYMV and PRSV,

Table 1. Powdery mildew severity on 26 Cucurbita pepo and four C. maxima pumpkin cultigens in 1996 and 1997.

\begin{tabular}{|c|c|c|c|c|c|c|}
\hline \multirow[b]{2}{*}{ Cultigen } & \multicolumn{2}{|c|}{$\begin{array}{c}\text { Powdery mildew } \\
\text { severity }(\%)^{z}\end{array}$} & \multicolumn{2}{|c|}{$\begin{array}{c}\text { Downy mildew } \\
\text { severity }(\%)^{\mathrm{y}}\end{array}$} & \multicolumn{2}{|c|}{$\begin{array}{c}\text { Foliar virus } \\
\text { severity }(\%)^{\mathrm{x}}\end{array}$} \\
\hline & $1996^{\mathrm{w}}$ & 1997 & $1996^{w}$ & 1997 & 1996 & 1997 \\
\hline \multicolumn{7}{|c|}{ C. реро } \\
\hline Appalachian & $39.5 \mathrm{a}-\mathrm{e}^{\mathrm{v}}$ & $46.8 \mathrm{a}-\mathrm{d}$ & $12.2 \mathrm{bc}$ & $1.5 \mathrm{a}-\mathrm{d}$ & $93.3 \mathrm{a}-\mathrm{e}$ & $93.6 \mathrm{a}-\mathrm{c}$ \\
\hline Autumn Gold & $45.1 \mathrm{a}-\mathrm{c}$ & $23.8 \mathrm{~b}-\mathrm{g}$ & $12.2 \mathrm{bc}$ & $0.4 \mathrm{~b}-\mathrm{d}$ & $96.4 \mathrm{a}-\mathrm{d}$ & $78.2 \mathrm{a}-\mathrm{d}$ \\
\hline Big Autumn & $62.5 \mathrm{a}$ & $8.3 \mathrm{gh}$ & $31.2 \mathrm{a}-\mathrm{c}$ & $0.1 \mathrm{~cd}$ & $91.5 \mathrm{a}-\mathrm{e}$ & $92.5 \mathrm{a}-\mathrm{d}$ \\
\hline Connecticut Field & $24.8 \mathrm{~b}-\mathrm{g}$ & $49.2 \mathrm{a}-\mathrm{c}$ & $12.2 \mathrm{bc}$ & $3.6 \mathrm{a}$ & $94.7 \mathrm{a}-\mathrm{e}$ & $72.2 \mathrm{a}-\mathrm{d}$ \\
\hline Funny Face & $45.8 \mathrm{a}-\mathrm{c}$ & $47.1 \mathrm{a}-\mathrm{d}$ & $37.5 \mathrm{ab}$ & $1.3 \mathrm{a}-\mathrm{d}$ & $68.4 \mathrm{~b}-\mathrm{f}$ & $92.6 \mathrm{a}-\mathrm{d}$ \\
\hline Ghost Rider & $44.0 \mathrm{a}-\mathrm{d}$ & $40.8 \mathrm{a}-\mathrm{d}$ & $24.8 \mathrm{a}-\mathrm{c}$ & $1.3 \mathrm{a}-\mathrm{d}$ & $89.4 \mathrm{a}-\mathrm{e}$ & $89.9 \mathrm{a}-\mathrm{d}$ \\
\hline HMX $6686^{\mathrm{u}}$ & $10.7 \mathrm{f}-\mathrm{h}$ & $0.1 \mathrm{i}$ & $18.5 \mathrm{a}-\mathrm{c}$ & $0.8 \mathrm{a}-\mathrm{d}$ & $94.0 \mathrm{a}-\mathrm{e}$ & $85.5 \mathrm{a}-\mathrm{d}$ \\
\hline HMX $6688^{u}$ & $12.2 \mathrm{e}-\mathrm{h}$ & $1.9 \mathrm{hi}$ & $20.2 \mathrm{a}-\mathrm{c}$ & $1.1 \mathrm{a}-\mathrm{d}$ & $96.9 \mathrm{a}-\mathrm{d}$ & $85.4 \mathrm{a}-\mathrm{d}$ \\
\hline Happy Jack & $54.2 \mathrm{ab}$ & $55.6 \mathrm{a}$ & $21.7 \mathrm{a}-\mathrm{c}$ & $0.8 \mathrm{a}-\mathrm{d}$ & $95.5 \mathrm{a}-\mathrm{e}$ & $99.3 \mathrm{a}$ \\
\hline Howden & $39.5 \mathrm{a}-\mathrm{e}$ & $50.5 \mathrm{ab}$ & $21.7 \mathrm{a}-\mathrm{c}$ & $3.6 \mathrm{a}$ & $93.3 \mathrm{a}-\mathrm{e}$ & $95.2 \mathrm{a}-\mathrm{c}$ \\
\hline Howden Biggie & $31.2 \mathrm{a}-\mathrm{f}$ & $30.9 \mathrm{a}-\mathrm{f}$ & $12.2 \mathrm{bc}$ & $0.8 \mathrm{a}-\mathrm{d}$ & $97.9 \mathrm{a}-\mathrm{c}$ & $81.6 \mathrm{a}-\mathrm{d}$ \\
\hline Jack of All Trades & $24.1 \mathrm{~b}-\mathrm{g}$ & $20.8 \mathrm{c}-\mathrm{g}$ & $26.5 \mathrm{a}-\mathrm{c}$ & $1.1 \mathrm{a}-\mathrm{d}$ & $84.0 \mathrm{a}-\mathrm{e}$ & $89.8 \mathrm{a}-\mathrm{d}$ \\
\hline Jackpot & $16.3 \mathrm{c}-\mathrm{h}$ & $27.2 \mathrm{a}-\mathrm{g}$ & $31.2 \mathrm{a}-\mathrm{c}$ & $0.1 \mathrm{~cd}$ & $92.4 \mathrm{a}-\mathrm{e}$ & $78.2 \mathrm{a}-\mathrm{d}$ \\
\hline Little Lantern & $18.5 \mathrm{c}-\mathrm{h}$ & $19.6 \mathrm{~d}-\mathrm{g}$ & $21.7 \mathrm{a}-\mathrm{c}$ & $0.4 \mathrm{~b}-\mathrm{d}$ & $100 \mathrm{a}$ & $91.4 \mathrm{a}-\mathrm{d}$ \\
\hline Magic Lantern ${ }^{\mathrm{u}}$ & $7.5 \mathrm{f}-\mathrm{h}$ & $2.1 \mathrm{hi}$ & $21.7 \mathrm{a}-\mathrm{c}$ & $2.1 \mathrm{a}-\mathrm{c}$ & $95.5 \mathrm{a}-\mathrm{e}$ & $94.3 \mathrm{a}-\mathrm{c}$ \\
\hline $\mathrm{Oz}$ & $62.5 \mathrm{a}$ & $19.6 \mathrm{~d}-\mathrm{g}$ & $31.2 \mathrm{a}-\mathrm{c}$ & $1.3 \mathrm{a}-\mathrm{d}$ & $98.7 \mathrm{ab}$ & $82.1 \mathrm{a}-\mathrm{d}$ \\
\hline Pankow's Field & $30.0 \mathrm{~b}-\mathrm{f}$ & $23.9 \mathrm{~b}-\mathrm{g}$ & $24.8 \mathrm{a}-\mathrm{c}$ & $1.9 \mathrm{a}-\mathrm{c}$ & $77.4 \mathrm{a}-\mathrm{f}$ & $76.9 \mathrm{a}-\mathrm{d}$ \\
\hline Pro Gold 500 & $68.4 \mathrm{a}$ & $23.9 \mathrm{~b}-\mathrm{g}$ & $24.8 \mathrm{a}-\mathrm{c}$ & $0.4 \mathrm{~b}-\mathrm{d}$ & $94.7 \mathrm{a}-\mathrm{e}$ & $72.9 \mathrm{a}-\mathrm{d}$ \\
\hline Pro Gold 510 & $45.1 \mathrm{a}-\mathrm{c}$ & $27.1 \mathrm{a}-\mathrm{g}$ & $24.8 \mathrm{a}-\mathrm{c}$ & $0.7 \mathrm{a}-\mathrm{d}$ & $95.7 \mathrm{a}-\mathrm{e}$ & $86.6 \mathrm{a}-\mathrm{d}$ \\
\hline Rocket & $44.9 \mathrm{a}-\mathrm{c}$ & $22.6 \mathrm{~b}-\mathrm{g}$ & $54.2 \mathrm{a}$ & $1.3 \mathrm{a}-\mathrm{d}$ & $88.8 \mathrm{a}-\mathrm{e}$ & $88.9 \mathrm{a}-\mathrm{d}$ \\
\hline Small Sugar & $39.5 \mathrm{a}-\mathrm{e}$ & $37.3 \mathrm{a}-\mathrm{e}$ & $15.3 \mathrm{bc}$ & $1.5 \mathrm{a}-\mathrm{d}$ & $96.7 \mathrm{a}-\mathrm{d}$ & $98.0 \mathrm{ab}$ \\
\hline Spirit & $30.4 \mathrm{a}-\mathrm{f}$ & $27.2 \mathrm{a}-\mathrm{g}$ & $28.0 \mathrm{a}-\mathrm{c}$ & $1.1 \mathrm{a}-\mathrm{d}$ & $95.4 \mathrm{a}-\mathrm{e}$ & $89.4 \mathrm{a}-\mathrm{d}$ \\
\hline Spookie & $54.2 \mathrm{ab}$ & $53.1 \mathrm{ab}$ & $15.3 \mathrm{bc}$ & $2.1 \mathrm{a}-\mathrm{c}$ & $97.9 \mathrm{a}-\mathrm{c}$ & $87.9 \mathrm{a}-\mathrm{d}$ \\
\hline Spooktacular & $24.1 \mathrm{~b}-\mathrm{g}$ & $14.3 \mathrm{e}-\mathrm{h}$ & $31.2 \mathrm{a}-\mathrm{c}$ & $0.7 \mathrm{a}-\mathrm{d}$ & $60.2 \mathrm{c}-\mathrm{f}$ & $80.2 \mathrm{a}-\mathrm{d}$ \\
\hline Tallman & $24.8 \mathrm{~b}-\mathrm{g}$ & $48.4 \mathrm{a}-\mathrm{d}$ & $15.3 \mathrm{bc}$ & $2.1 \mathrm{a}-\mathrm{c}$ & $93.6 \mathrm{a}-\mathrm{e}$ & $58.6 \mathrm{~cd}$ \\
\hline Tom Fox & $24.8 \mathrm{~b}-\mathrm{g}$ & $50.5 \mathrm{ab}$ & $21.7 \mathrm{a}-\mathrm{c}$ & $2.8 \mathrm{ab}$ & $98.0 \mathrm{a}-\mathrm{c}$ & $85.5 \mathrm{a}-\mathrm{d}$ \\
\hline Trickster & $15.0 \mathrm{~d}-\mathrm{h}$ & $28.5 \mathrm{a}-\mathrm{g}$ & $43.8 \mathrm{ab}$ & $0.1 \mathrm{~cd}$ & $98.9 \mathrm{ab}$ & $91.3 \mathrm{a}-\mathrm{d}$ \\
\hline Wizard & $54.2 \mathrm{ab}$ & $59.8 \mathrm{a}$ & $31.2 \mathrm{a}-\mathrm{c}$ & $2.8 \mathrm{ab}$ & $95.4 \mathrm{a}-\mathrm{e}$ & $97.4 \mathrm{ab}$ \\
\hline \multicolumn{7}{|c|}{ C. maxima } \\
\hline Big Max & $15.3 \mathrm{~d}-\mathrm{h}$ & $27.2 \mathrm{a}-\mathrm{g}$ & $6.7 \mathrm{c}$ & $0.0 \mathrm{~d}$ & $53.5 \mathrm{ef}$ & $67.1 \mathrm{~b}-\mathrm{d}$ \\
\hline Lumina & $2.7 \mathrm{~h}$ & $3.6 \mathrm{hi}$ & $18.5 \mathrm{a}-\mathrm{c}$ & $0.7 \mathrm{a}-\mathrm{d}$ & $58.5 \mathrm{~d}-\mathrm{f}$ & $50.0 \mathrm{~d}$ \\
\hline Mammoth Gold & $24.8 \mathrm{~b}-\mathrm{g}$ & $22.6 \mathrm{~b}-\mathrm{g}$ & $6.0 \mathrm{c}$ & $0.1 \mathrm{~cd}$ & $64.7 \mathrm{~b}-\mathrm{f}$ & $64.7 \mathrm{~b}-\mathrm{d}$ \\
\hline Rouge Vif d'Etamps & $4.5 \mathrm{hg}$ & $11.8 \mathrm{f}-\mathrm{h}$ & $18.5 \mathrm{a}-\mathrm{c}$ & $0.1 \mathrm{~cd}$ & $31.9 \mathrm{f}$ & $70.6 \mathrm{a}-\mathrm{d}$ \\
\hline
\end{tabular}

${ }^{2}$ Percentage of upper and lower leaf surface area covered with powdery mildew on 19 Aug. 1996 and 5 Sept. 1997 , respectively.

yPercentage of upper and lower leaf surface area covered with downy mildew on 19 Aug. 1996 and 5 Sept. 1997, respectively.

xPercentage of leaf surface area with virus symptoms on 29 Aug. 1996 and 16 Sept. 1997, respectively. ${ }^{\text {w }}$ Cultigen $\times$ year interaction significant at $P \leq 0.0001$.

${ }^{v}$ Mean separation within years by Waller-Duncan k ratio $t$ test $; \mathrm{k}=500$ (approximates $P=0.01$ ) for powdery mildew and virus and $\mathrm{k}=100$ (approximates $P=0.05$ ) for downy mildew.

"Cultigen with resistance to powdery mildew. 
whereas samples of leaves with mosaic were positive for only ZYMV; WMV was not detected. Rankings of the cultigens based on foliar virus symptoms differed in the 2 years (Table 1). In 1996, percentage leaf area with symptoms was significantly less in 'Rouge Vif d'Etamps,' 'Big Max,' 'Lumina,' and 'Spooktacular' than in 'Little Lantern,' 'Trickster,' and 'Oz'. In 1997, 'Lumina' and 'Tallman' had significantly less foliage with symptoms than did 'Happy Jack,' 'Small Sugar,' and 'Wizard.' In both years, C. maxima cultivars had fewer symptoms overall than did $C$. pepo cultigens $(P \leq 0.0001)$.

Yield of fruit. Fruit numbers were low for most cultivars in both years. In 1996, harvest was $\approx 3$ weeks earlier than anticipated because of accelerated foliage senescence. Choanephora wet rot, caused by Choanephora cucurbitarum (Berk. \& Ravenel) Thaxt., was observed on decaying young fruit in both years. Cultivars Autumn Gold, Happy Jack, and Tom Fox set no fruit in 1996, but all cultigens except Big Autumn produced at least one fruit per plot in 1997. Most cultivars produced more total and marketable fruit in 1997 than in 1996; however, 'Spooktacular', 'Funny Face', 'Oz', and 'Trickster' produced more marketable-quality fruit in 1996 than in 1997 (Table 2). HMX 6686 had the highest number of total fruit both years and 'Spooktacular' and 'Spookie' had the highest numbers of marketable-quality fruit in 1996 and 1997, respectively. Among $C$. maxima cultivars, Rouge Vif d'Etamps yielded the most total fruit both years, but marketable yields were low for all four C. maxima cultivars. Most of the nonmarketable fruits were disfigured with warts or knobs or had uneven green-orange coloration due to virus infection.

Mean fruit weight. In 1996, mean fruit weights were uniformly low (Table 2). In 1997, weights for 13 cultivars fell within the ranges of expected values $(<4.5,4.5$ to 9.1 , and $\geq 9.1 \mathrm{~kg}$ for cultigens with small, medium, and large fruit, respectively) (Table 2). Five cultivars expected to produce large fruit had fruit weights less than $9.1 \mathrm{~kg}$ and nine cultivars expected to produce medium-sized fruit had fruit weights $<4.5 \mathrm{~kg}$. Two cultivars, 'Rouge
Vif d'Etamps' and 'Tallman', produced fruit weighing more than the upper threshold for medium-sized fruit. By size class, mean fruit weights for cultigens with small $(0.36 \mathrm{~kg})$, medium $(0.82 \mathrm{~kg})$, and large fruits $(1.25 \mathrm{~kg})$ also were very low in 1996. In 1997, weights for the three size classes were similar to expected values: $10.1 \mathrm{~kg}$ (range 22.1 to 5.3) for large-, $5.1 \mathrm{~kg}$ (range 12.6 to 2.0) for medium, and $1.8 \mathrm{~kg}$ (range 2.6 to 1.1) for small-fruited cultigens. In both years, class means for the three sizes differed significantly from each other $(P \leq 0.01$ in 1996 and $P \leq 0.0001$ in 1997).

Comparison of classes of cultivars. Because of the large number of cultivars examined in this study, means also were compared by classes of cultivars (Table 3 ). Cultivars were assigned to classes according to species, expected days to maturity, expected fruit size, growth habit (vine or semi-bush) and type of pollination (open-pollinated or hybrid) (Tables 1 and 2). Cucurbita maxima cultivars, as a group, produced significantly higher numbers of total fruit than did C. pepo cultigens in both

Table 2. Vine and fruit characteristics of pumpkin cultigens, number of total and marketable-quality fruit produced, and mean fruit weight in 1996 and $1997 .{ }^{2}$

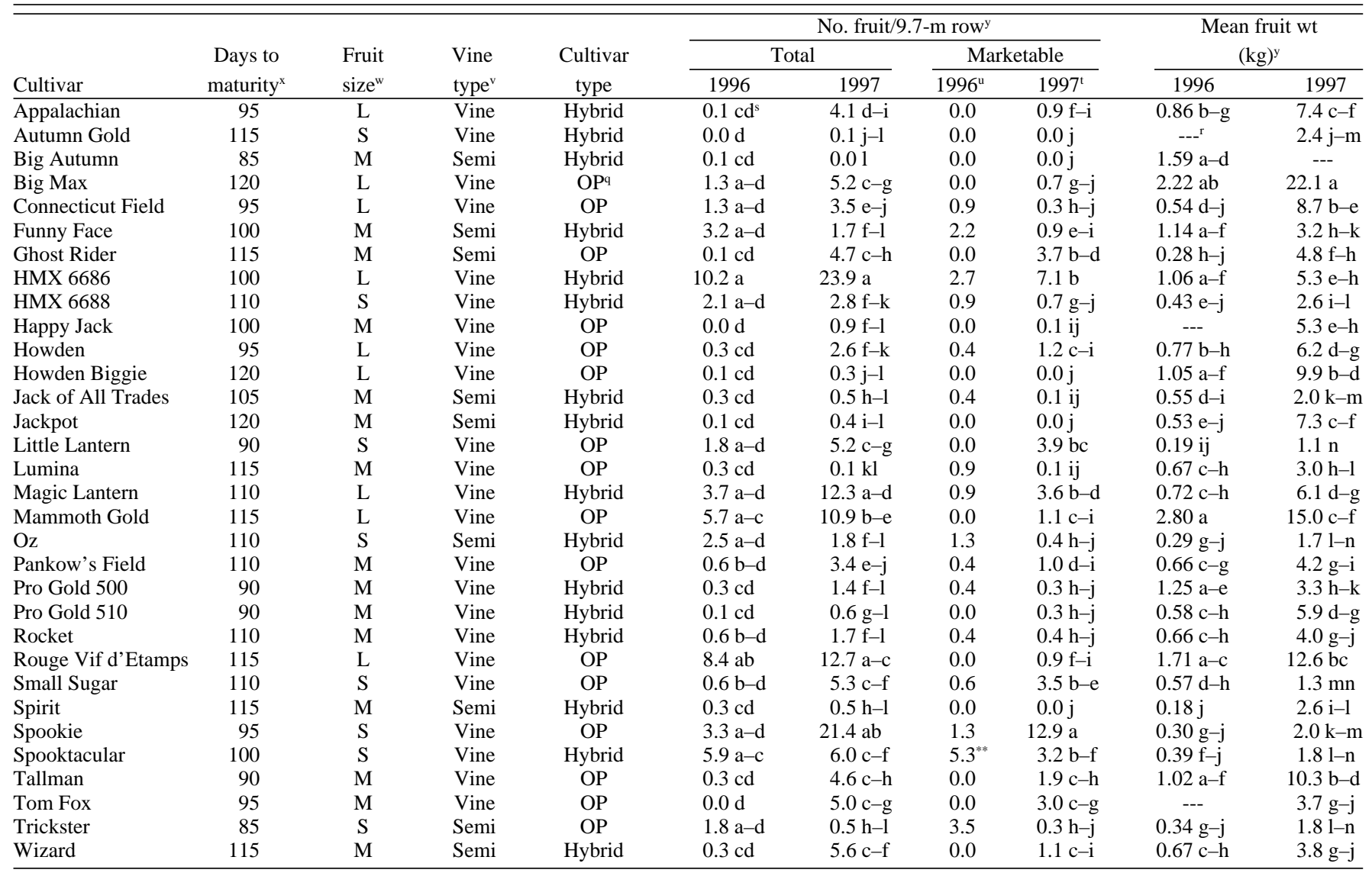

${ }^{2}$ Cultigen $\times$ year interaction significant at $P \leq 0.01$.

${ }^{\mathrm{y}}$ Means for three replications in 1996 and four replications in 1997.

${ }^{x}$ Expected days to maturity based on seed company descriptions.

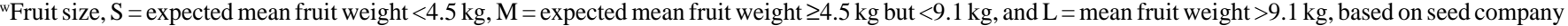
descriptions.

${ }^{\mathrm{v}}$ Vine $=$ vining plant type, semi $=$ semi-bush type of plant, based on field observations

"Fruit with no decay, intact stems, and no disfiguration or color-breaking due to virus.

'Fruit with no decay, intact stems, and $<20 \%$ surface area with virus symptoms.

${ }^{\mathrm{s}}$ Mean separation by Waller-Duncan $\mathrm{k}$ ratio $t$ test; $\mathrm{k}=500$ (approximates $P=0.01$ ).

${ }^{\mathrm{r}}$ No fruit produced in this year.

${ }^{q}$ Open-pollinated.

***Only value significantly different from 0.0 in 1996, Dunnett's $t$ test, $P \leq 0.01$. 
years (Table 3 ). However, the number of marketable fruit did not differ significantly between the two species. On average, long- and mid-season cultigens of both species produced greater numbers of total and marketable fruit than did short-season cultigens, except for long-season cultigens in 1996 (Table 3). Smallfruited cultigens produced more total and marketable fruit than did cultigens with mediumsized fruit both years. Likewise, cultigens with large fruit produced more fruit than did cultigens with medium-sized fruit, except for marketable fruit of both species in 1996. However, number of marketable fruit generally did not differ between small- and large-fruited cultigens (data not shown). Vining cultigens produced more fruit than did semi-bush cultigens in 1997, but not in 1996. Open-pollinated cultivars produced more fruit than did hybrid cultigens in 1997 but not in 1996.

\section{Discussion}

In general, all four C. maxima cultivars and the three $C$. pepo cultigens with powdery mildew resistance exhibited significantly lower powdery mildew severities than did susceptible $C$. pepo cultivars. These results were consistent in both years, even though powdery mildew was more severe in 1996 than in 1997. When tested in other locations, 'Magic Lantern' (HMX 5683) and HMX 6686 also had less powdery mildew than standard susceptible cultivars (McGrath, 1998; McGrath and Sieczka, 1997; Straw et al., 1998). We found the resistance of HMX 6688 to be as effective as the other two powdery mildew-resistant lines we tested, as reported by McGrath and Sieczka (1997). However, in Ohio ratings for HMX 6688 were not significantly different from ratings for 'Jackpot,' which is susceptible to powdery mildew (Precheur etal., 1998). Because 'Spookie' had good marketable yields despite high levels of powdery mildew, it may have some tolerance to this pathogen.

Although we did not evaluate cultivars without applying fungicides, reducing the amount or frequency of fungicides applied to pumpkin cultivars with resistance to powdery mildew may be possible, as has been done successfully with resistant summer squash cultivars (McGrath, 1996). A cultural control to supplement fungicidal control of powdery mildew is needed, since in many areas of the United States the fungus is resistant to benomyl and triadimefon, the two most widely-used systemic fungicides effective against powdery mildew on cucurbits (McGrath et al., 1996). However, powdery mildew-resistant cultivars cannot be grown without fungicides, based on trials conducted in Ohio (Precheur et al., 1998) and New York (McGrath, 1998). Without fungicide, 'Magic Lantern' had less powdery mildew than a related susceptible experimental line, but more than the same line that was sprayed with fungicide (McGrath, 1998).

In North Carolina, PRSV and WMV were detected on summer squash one year, whereas PRSV, WMV, and ZYMV were detected the following year (Schultheis and Walters, 1998).

Table 3. Comparison of numbers ${ }^{2}$ of total and marketable fruit in 1996 and 1997 by different classes of 26 Cucurbita pepo and four C. maxima pumpkin cultigens.

\begin{tabular}{|c|c|c|c|c|}
\hline \multirow[b]{3}{*}{ Contrast $^{\mathrm{x}}$} & \multicolumn{4}{|c|}{$P>\mathrm{F}_{\text {value }}$} \\
\hline & \multicolumn{2}{|c|}{ Total fruit no. } & \multicolumn{2}{|c|}{ Marketable fruit no. } \\
\hline & 1996 & 1997 & 1996 & 1997 \\
\hline \multicolumn{5}{|l|}{ C. maxima and C. pepo cultigens } \\
\hline C. maxima vs. C. pepo & 0.0052 & 0.0091 & 0.11 & 0.17 \\
\hline Vine vs. semi-bush & 0.20 & 0.0001 & 0.84 & 0.0001 \\
\hline Open-pollinated vs. hybrid & 0.78 & 0.0025 & $(0.023)^{\mathrm{w}}$ & 0.0011 \\
\hline Long-season vs. short-season ${ }^{\mathrm{v}}$ & 0.049 & 0.0001 & 0.20 & 0.0001 \\
\hline Midseason vs. short-season ${ }^{v}$ & 0.022 & 0.0001 & 0.14 & 0.0001 \\
\hline Large-fruited vs. medium-fruited ${ }^{u}$ & 0.003 & 0.0001 & 0.22 & 0.005 \\
\hline Small-fruited vs. medium-fruited ${ }^{u}$ & 0.006 & 0.002 & 0.0007 & 0.0001 \\
\hline \multicolumn{5}{|l|}{ C. pepo cultigens only } \\
\hline Vine vs. semi-bush & 0.54 & 0.0001 & 0.85 & 0.0001 \\
\hline Open-pollinated vs. hybrid & 0.14 & 0.025 & $(0.069)^{\mathrm{w}}$ & 0.0001 \\
\hline Long-season vs. short-season & 0.46 & 0.0001 & 0.47 & 0.0001 \\
\hline Midseason vs. short-season & 0.027 & 0.0002 & 0.035 & 0.0001 \\
\hline Large-fruited vs. medium-fruited & 0.007 & 0.0001 & 0.057 & 0.006 \\
\hline Small-fruited vs. medium-fruited & 0.001 & 0.0007 & 0.0007 & 0.0001 \\
\hline
\end{tabular}

${ }^{\mathrm{z}}$ Number of fruit per 9.7-m row. Means for three replications in 1996 and four replications in 1997.

yProbability that the mean for the class listed first was greater than the mean for the second class.

'Preplanned single-degree-of-freedom contrasts.

"The mean for the class listed second was greater than the mean for the first class.

"Long-, mid-, and short-season are 110-120, 100-105, and 85-95 d to maturity, respectively.

"Large-fruited $=$ expected average fruit weight $>9.1 \mathrm{~kg}$, medium $=\geq 4.5 \mathrm{~kg}$ but $<9.1 \mathrm{~kg}$, and small $=<4.5 \mathrm{~kg}$.

Similarly, we detected PRSV, WMV, and ZYMV in 1996 but only PRSV and ZYMV in 1997. Apparently, PRSV is one of the most common cucurbit viruses, whereas incidence of ZYMV and WMV can vary by year and location. As noted by Schultheis and Walters (1998), cultivars with resistance to PRSV are needed to improve marketable yields of fallgrown cucurbits in the southeastern United States.

In summer squash, fruit expression of virus symptoms did not appear to be related to the severity of foliar symptoms (Schultheis and Walters, 1998). Similarly, 'Small Sugar' and 'Little Lantern' pumpkin had good yields of marketable-quality fruit, even though leaf symptoms of virus were severe. In contrast, although the $C$. maxima cultivars had fewer foliar virus symptoms than $C$. pepo cultigens, most of the fruits graded as unmarketable had color-breaking and disfiguration typical of virus infection (Zitter et al., 1996). The two cultivars with the $P y$ gene, 'Big Autumn' and 'Autumn Gold', produced few fruit, some of which still showed color-breaking due to virus. Powdery mildew severity also was not statistically correlated with marketable yield of fruit, probably because downy mildew and virus also reduced yields.

Yields of total and marketable fruit were greater in 1997 than in 1996. Most cultivars seemed to require more than the 1.8-m spacing allowed in 1996, and turning the fragile vines damaged them, possibly reducing yields. Plant spacing of $0.9 \mathrm{~m}$ within rows in 1996 also may have been too close for optimum yields. In addition, downy and powdery mildew pressure was higher earlier in the season in 1996 than in 1997 , which probably reduced yields as well. Using lower rates of fungicides for most of the 1996 season may have contributed to the higher disease pressure.

As a group, short-season cultigens $(<95 \mathrm{~d}$ to maturity) had lower total and marketable yields than did mid- or long-season cultigens. Because of the later transplanting date used for short-season cultigens in these tests, they may have been exposed at transplanting to virus or powdery mildew inoculum from the earlierplanted cultigens. Cultigens with small $(<4.5$ $\mathrm{kg})$ or large $(\geq 9.1 \mathrm{~kg})$ fruit produced greater numbers of fruit than cultigens with mediumsized fruit $(\geq 4.5$ but $<9.1 \mathrm{~kg})$. The lower yields of cultivars with medium-sized fruit may be explained partially by vining type, since seven of the nine medium-fruited cultivars were semibush types that, as a group, had lower yields than vining types in 1997. In addition, all five top-yielding cultigens, Spookie, HMX 6686, Spooktacular, Magic Lantern, and Small Sugar, are vining types. In 1997, 13 of the 32 cultigens tested produced fruit that reached the expected sizes, whereas 14 produced fruit that were smaller than expected. Only two $C$. pepo cultivars, 'Howden Biggie' and 'Tallman', produced large fruit $(\geq 9.1 \mathrm{~kg})$ and neither of these cultivars had high yields.

Based on these 2 years of testing in one location, none of the 32 cultivars we examined were particularly well-adapted for production in the southeastern coastal plain, very likely because no cultivar combines resistances to powdery mildew, downy mildew, PRSV, ZYMV, and WMV. The two best-yielding cultivars were 'Spooktacular' and 'Magic Lantern'. Although 'Spookie' had a higher mean marketable yield (8.4 fruit per $9.7-\mathrm{m}$ row of eight plants) over the 2 years than did 'Spooktacular' (4.5 fruit), 'Spooktacular' had a much lower variance (20.0 compared with 85.4), indicating that it was a more reliable producer. 'Spooktacular' produced small fruit, suitable for "pick-your-own" and other direct markets. 'Magic Lantern,' which is resistant to powdery mildew, produced medium-sized fruit, suitable for both direct and wholesale markets. Because few cultivars yielded well under the hot, humid conditions, there is a need to develop pumpkin cultivars that are adapted to production in the lower coastal plains of the southeastern United States. 


\section{Literature Cited}

Bost, S.C., C.A. Mullins, G. Evans, R.A. Straw, and K.E. Johnson. 1991. Pumpkin cultivar performance under fungicide treated and non-treated conditions. Biol. Cult. Tests 6:28.

Horsfall, J.G. and R.W. Barratt. 1945. An improved system for measuring plant diseases. Phytopathology 35:655. (Abstr.)

Kemble, J.M., Sikora, E.J., Zehnder, G.W., and E. Bauske. 1997. Guide to commercial pumpkin and winter squash production. Alabama Coop. Ext. Sys. Circ. ANR-1041. Alabama A\&M and Auburn Univ.

McGrath, M.T. 1996. Efficacy and economics of genetic control compared with chemical control for managing powdery mildew of summer squash. Biol. Cult. Tests 11:117.

McGrath, M.T. 1998. Susceptibility to powdery mildew and yield of pumpkin experimentals. Biol. Cult. Tests 13:178.

McGrath, M.T. and J.B. Sieczka. 1997. Susceptibility to powdery mildew and horticultural characteristics of resistant pumpkin experimentals. Biol. Cult. Tests 12:161.

McGrath, M.T., H. Staniszewska, N. Shishkoff, and G. Casella. 1996. Fungicide sensitivity of Sphaerothecafuliginea populations in the United States. Plant Dis. 80:679-703.

Olson, D.L., J.R. Nechols, and C.W. Marr. 1995. Consumers' preference for insecticide-free pumpkins in eastern Kansas. HortTechnology 5:274-276.

Precheur, R.J., R.M. Riedel, H. Bartholomew, and J. Walker. 1994. Susceptibility of pumpkin varieties to powdery mildew. Biol. Cult. Tests 9:41.

Precheur, R.J., R.M. Riedel, and C. Welty. 1998 Susceptibility of pumpkin varieties to powdery mildew. Biol. Cult. Tests 13:176.

Schultheis, J.R. and S.A. Walters. 1998. Yield and virus resistance of summer squash cultivars and breeding lines in North Carolina. HortTechnology 8:31-39.

Shoemaker, P.B. 1994. Fungicides for downy and powdery mildew on pumpkin. Fungic. Nematic. Tests 49:145.

Snyder, R.G., F. Killebrew, and J.A. Fox. 1993. Evaluation of precocious yellow gene squash cultivars for tolerance to watermelon mosaic virus. HortTechnology 3:421-423.

Straw, R.A., C.A. Mullins, N.B. Shamiyeh, and B.R. Gerhardt. 1998. Tolerance of pumpkin cultivars to downy and powdery mildew. Biol. Cult. Tests 13:172.

Zitter, T.A., D.L. Hopkins, and C.E. Thomas (eds.). 1996. Compendium of cucurbit diseases. APS Press, St. Paul, Minn. 